\title{
PREVALENSI GEN tdh DAN trh Vibrio parahaemolyticus PADA UDANG VANAME DI WILAYAH INDRAMAYU, JAWA BARAT
}

\section{Prevalence of tdh and trh Genes of Vibrio parahaemolyticus in Shrimp (Litopenaeus vannamei) from Indramayu, West Java}

\author{
Yusma Yennie $^{1^{*}}$, Ratih Dewanti Hariyadi2,3, dan Achmad Poernomo ${ }^{1}$ \\ ${ }^{1}$ Balai Besar Penelitian dan Pengembangan Pengolahan Produk dan Bioteknologi Kelautan dan Perikanan, \\ Jl. K.S. Tubun Petamburan VI, Jakarta Pusat, Indonesia \\ ${ }^{2}$ Departemen IImu dan Teknologi Pangan, Fakultas Teknologi Pertanian, Institut Pertanian Bogor, Bogor, Indonesia \\ ${ }^{3}$ Southeast Asian Food Agricultural Science and Technology (SEAFAST) Center, Institut Pertanian Bogor, Bogor, Indonesia \\ * Korespondensi Penulis: yenni.yusma@gmail.com
}

Diterima: 4 Mei 2015; Disetujui: 10 Juni 2015

\begin{abstract}
ABSTRAK
Penelitian ini bertujuan untuk mengetahui prevalensi Vibrio parahaemolyticus patogenik pada udang vaname yang berasal dari tambak tradisional dan intensif berdasarkan keberadaan gen tdh dan trh. Isolasi dan konfirmasi Vibrio parahaemolyticus mengacu pada BAM (2004), yang dilanjutkan dengan konfirmasi gen tdh dan trh Vibrio parahaemolyticus menggunakan metode PCR. Hasil identifikasi menunjukkan bahwa sebanyak 16/32(50\%) dan 6/32 (18,8\%) udang dari tambak tradisional dan intensif positif Vibrio parahaemolyticus. Berdasarkan gen tdh, ditemukan Vibrio parahaemolyticus patogenik pada udang tambak tradisional dan intensif berturut-turut adalah $81 \%(13 / 16)$ dan 50\% (3/6). Sementara itu, jika didasarkan pada gen trh, Vibrio parahaemolyticus patogenik pada udang tambak tradisional dan intensif berturut-turut adalah $15 / 16(93,8 \%)$ dan $4 / 6(66,7 \%)$. Secara keseluruhan prevalensi udang vaname yang positif gen $t d h$ adalah sebesar $72,2 \%(16 / 22)$ gen trh sebesar 86,4\% (19/22) dan yang memiliki kedua gen adalah sebanyak $63,6 \%(14 / 22)$.
\end{abstract}

KATA KUNCl: Vibrio parahaemolyticus, gen $t d h$, gen trh, Litopenaeus vannamei

\section{ABSTRACT}

This research aimed to know the prevalence of pathogenic Vibrio parahaemolyticus in shrimp (Litopenaeus vannamei) from traditional and intensive shrimp ponds based on their possession of tdh and trh genes. Bacterial isolation and phenotypic characterization was carried out using FDA BAM (2004), and confirmation based on virulent factor gene (tdh and trh genes) was conducted by Polymerase Chain Reaction (PCR). The result showed that 16/32(50\%) and 6/32 (18.8\%) shrimp samples from traditional and intensive ponds contained Vibrio parahaemolyticus, respectively. Pathogenic Vibrio parahaemolyticus due to their possession of th gene isolated from traditional and intensive ponds were 81\%(13/16) and 50\% (3/6), respectively. When trh gene was used as the basic for classification, pathogenic vibrio parahaemolyticus obtained from traditional and intensive ponds were reaching up 15/16 (93.8\%) and 4/6 (66.7\%) respectively. Out of the 22 Vibrio parahaemolyticus isolates, 16 (72.7\%) were pathogenic based on the possession of gene encoding for tdh and 19 (86.4\%) can be classified as pathogen based on the trh gene. As many as 14 out of 22 (63.6\%) Vibrio parahaemolyticus isolates owned both tdh and trh genes.

KEYWORDS: Vibrio parahaemolyticus, tdh and trh genes, Litopenaeus vannamei

\section{PENDAHULUAN}

Udang merupakan salah satu komoditas unggulan dalam program revitalisasi Kementerian Kelautan dan Perikanan (KKP). Kontribusi udang terhadap total nilai ekspor perikanan Indonesia pada awal tahun 2014, sebesar 45\% dengan total volume ekspor
293.000 ton (Pusat Data, Statistik dan Informasi, 2014). Komoditas udang yang sampai saat ini berkembang pesat dari sisi produksi dan memiliki pasar yang cukup tinggi adalah udang vaname. Udang vaname (Litopenaeus vannamei) banyak dibudidayakan karena lebih tahan penyakit, memiliki waktu pemeliharaan yang lebih singkat (30-120 hari 
per siklus), dan juga hemat pakan. Salah satu daerah penghasil udang vaname terbesar di Jawa Barat dengan kontribusi produksi mencapai $73,61 \%$ adalah Kabupaten Indramayu. Produksi udang vaname di Indramayu cukup besar karena terdapat 11 kecamatan yaitu Kecamatan Krangkeng, Indramayu, Pasekan, Cantigi, Patrol dan Losarang yang berada di pesisir dan merupakan area budidaya tambak. Budidaya udang vaname di Kabupaten Indramayu mencapai puncaknya pada tahun 2012 melalui program industrialisasi udang vaname yang dicanangkan oleh Kementerian Kelautan dan Perikanan

Namun demikian muncul berbagai permasalahan yang terkait dengan ekspor udang di antaranya adalah kasus penolakan ekspor udang Indonesia. Hal ini berdampak pada kerugian materil yang cukup besar bagi industri pengolahan udang. Salah satu penyebab penolakan ekspor udang adalah akibat kontaminasi mikroba patogen yaitu Vibrio parahemolyticus.

Vibrio parahaemolyticus merupakan flora normal di lingkungan perairan payau dan salah satu spesies Vibrio spp. yang bersifat patogen terhadap komoditas udang maupun pada manusia (DePaola et al., 2000). Keberadaan V. parahaemolyticus patogenik pada produk perikanan dapat menyebabkan penyakit bawaan pangan (foodborne disease) pada manusia melalui konsumsi pangan mentah atau pengolahan yang kurang sempurna (Venkitanarayanan \& Doyle, 2001; Potasman et al., 2002; Farmer et al., 2003; Eja et al., 2008; Newton et al., 2012; Zarei et al., 2012; Lutz et al., 2013). Hal ini juga dapat disebabkan oleh kontaminasi silang antar pangan olahan dan mentah atau melalui pencucian pangan dengan air yang mengandung $V$. parahaemolyticus (Daniels et al., 2000).

Kemampuan V. parahaemolyticus sebagai penyebab penyakit pada manusia umumnya dihubungkan dengan produksi hemolisin oleh bakteri ini yang dikenal dengan Thermostable Direct Hemolysin (TDH) dan Thermostable Direct Hemolysinrelated Hemolysin (TRH) (Honda \& lida, 1993; Nishibuchi \& Kaper, 1995; Makino et al., 2003; (Brobergetal et al., 2011). Thermostable Direct Hemolysin (TDH) dikenal sebagai faktor virulensi karena aktivitas $\beta$ hemolisisnya yang dapat melisis membran sel darah merah sehingga mengakibatkan gastroenteritis. Keberadaan TDH ditandai dengan adanya zona bening pada media agar Wagatsuma , di mana $V$. parahaemolyticus ditumbuhkan dan hal ini dikenal dengan istilah Fenomena Kanagawa (KP+). Keberadaan KP+ terkait dengan produksi TDH, yang dapat menyebabkan lisis pada membran sel darah merah melalui pembentukan pori sehingga beberapa ion masuk ke dalam sel dan terjadi pembengkakan sel yang mengakibatkan kematian sel karena ketidakseimbangan ion (Bhunia, 2008). Thermostable direct hemolysin-related hemolysin (TRH) disebut sebagai faktor virulensi lain dari V. parahaemolyticus, di mana keberadaannya dikaitkan dengan hasil Fenomena Kanagawa negatif (KP-) tetapi dapat menyebabkan gastroenteritis. Gen trh umumnya dikaitkan dengan $V$. parahaemolyticus yang menunjukkan hasil urease yang positif sehingga sering dijadikan indikator untuk identifikasi $V$. parahaemolyticus patogenik walaupun tidak mutlak (Suthienkul et al., 1995; Kaufman et al., 2002). Shirai et al. (1990) menyatakan bahwa 52 galur dari sampel klinis 8 pasien diare hanya memproduksi TRH sehingga disebut juga sebagai gen patogen $V$. parahaemolyticus.

Penelitian ini bertujuan untuk mengetahui prevalensi V. parahaemolyticus patogenik berdasarkan gen penyandi faktor virulensinya (tdh dan trh) pada udang vaname (Litopenaeus vannamei) yang berasal dari tambak tradisional dan intensif di Indramayu, Jawa Barat.

\section{BAHAN DAN METODE}

Sampel udang diperoleh dari tambak tradisional yang berlokasi di Kecamatan Cantigi yaitu Desa Cangkring (5 petak tambak), Cantigi Kulon (2 petak tambak), Cantigi Wetan (1 petak tambak) dan Lamaran Tarung (8 petak tambak). Sementara itu untuk tambak intensif, seluruh sampel berasal dari satu areal budidaya tambak sebanyak 16 petak tambak yang berlokasi di Kecamatan Patrol. Jenis udang yang diambil adalah udang vaname siap panen dengan umur pemeliharaan berkisar di atas 2,5 bulan. Periode pengambilan sampel disesuaikan dengan waktu panen tambak yang diperoleh berdasarkan informasi penyuluh Dinas Kelautan dan Perikanan Kabupaten Indramayu yang ditempatkan di kecamatan. Pengambilan sampel dilakukan 2 kali yaitu pada bulan Agustus dan Nopember 2010. Udang yang diambil berkisar 80-90 ekor/kg di tambak tradisional dan 7080 ekor/kg dari tambak intensif. Udang diambil pada 4 titik di setiap petak tambak dengan total berat sampel per petak tambak berkisar $500 \mathrm{~g}$. Sampel secara aseptis dimasukkan ke dalam plastik steril lalu ditempatkan pada cool box yang berisi es curah dan dibawa ke laboratorium untuk dilakukan analisis.

Isolasi dilakukan dengan cara menambahkan $25 \mathrm{~g}$ sampel ke dalam $225 \mathrm{ml}$ media pengayaan Alkaline Saline Peptone Water (ASPW, Oxiod, England) dan diinkubasikan pada suhu $37^{\circ} \mathrm{C}$ selama 24 jam. Homogenat dari media ASPW diinokulasikan ke media agar selektif Thiosulfate Citrate Bile Salt Sucrose (TCBS, Oxoid, England) dan diinkubasi pada suhu $37{ }^{\circ} \mathrm{C}$ selama 24 jam. Koloni tipikal 
V. parahaemolyticus sebanyak 2-3 koloni diinokulasikan pada media agar miring Tryptic Soy Agar (TSA, Oxoid, England) ditambah 2,5\% NaCl dan diinkubasi pada suhu $37^{\circ} \mathrm{C}$ selama 24 jam. Konfirmasi V. parahaemolyticus berdasarkan sifat biokimiawi dilakukan menggunakan API 20 E biochemical test kit (Biomerieux, France) (Kaysner \& DePaola, 2004).

Konfirmasi $V$. parahaemolyticus patogenik yang didasarkan pada gen spesifik tdh dan trh dilakukan dengan menggunakan metode Polymerase Chain Reaction (PCR). Pada tahap awal dilakukan isolasi DNA genom dengan metode fenol kloroform. Isolat $V$. parahaemolyticus yang telah diinkubasikan pada media Tryptic Soy Broth (TSB, Oxoid, England) ditambah 2,5\% NaCl selama 24 jam, disentrifugasi pada kecepatan 13.500 rpm selama 5 menit sehingga terbentuk pelet. Sodium Dodecyl Sulphate (SDS) 10\% ditambahkan pada pelet dan dihomogenisasikan kemudian ditambahkan proteinase- $K$ dan diinkubasi pada suhu $37{ }^{\circ} \mathrm{C}$ selama 1 jam. RNase $10 \mu \mathrm{l}$, Cetyiltrimethyl Ammonium Bromide (CTAB)/ $\mathrm{NaCl}$ (10\% CTAB dalam $0,7 \mathrm{M} \mathrm{NaCl}$ ), dan $\mathrm{NaCl} 5 \mathrm{M}$ kemudian ditambahkan pada sampel dan diinkubasikan pada suhu $65^{\circ} \mathrm{C}$ selama $10-20$ menit. Campuran fenol:kloroform:isoamilalkohol (25:24:1) ditambahkan ke dalam sampel dengan rasio 1:1 lalu dihomogenisasikan. Selanjutnya dilakukan sentrifugasi pada 13.500 rpm selama 10 menit. Fase cairan dipindahkan ke microtube $1,5 \mathrm{ml}$, lalu ditambahkan kloroform dan disentrifugasi pada 13.500 rpm selama 10 menit. Sodium asetat dan isopropanol ditambahkan dan sampel diinkubasikan pada suhu $-20^{\circ} \mathrm{C}$ selama $30-60$ menit dan disentrifugasi pada 13.500 rpm selama 10 menit. Sampel dicuci dengan etanol $70 \%$ dan disentrifugasi. Pelet dikeringkan lalu diresuspensi dalam $100 \mu$ l bufer TE dan disimpan di freezer $-20^{\circ} \mathrm{C}$ sebelum digunakan (Ausubel et al., 1987; Brown, 1992).

Amplifikasi dilakukan dengan menggunakan sepasang primer spesifik gen penyandi tdh yaitu GGT ACTAAATGG CTG ACA TC dan CCA CTA CCA CTC TCA TAT GC pada pita 251bp dan sepasang primer spesifik gen penyadi trh yaitu GGC TCA AAA TGG TTAAGC G dan CAT TTC CGC TCT CAT ATG C pada pita 250bp (Tada et al., 1992). Penentuan primer spesifik untuk mengidentifikasi gen $t d h$ dilakukan berdasarkan hasil terbaik dari 6 kombinasi pasangan primer yang menyandikan gen tdh2. Gen tdh2 adalah salah satu dari 2 sub unit identik gen $t d h$ yang dimiliki oleh galur $V$. parahaemolyticus patogenik. Pasangan primer gen $t d h$ yang paling spesifik berdasarkan hasil penelitian ini, terletak pada daerah antara 256-506 dengan ukuran amplikon $251 \mathrm{bp}$. Sedangkan untuk gen trh dipilih 6 kombinasi pasangan primer yang mewakili gen trh1 dan trh2. Hasil penelitian menyebutkan bahwa pasangan primer spesifik untuk mengidentifikasi toksin TRH adalah primer yang terletak pada daerah antara 256-505 dengan ukuran amplikon 250 bp. Berdasarkan hal tersebut di atas, pasangan primer ini digunakan untuk mengidentifikasi $V$. parahaemolyticus patogenik pada sampel udang tambak.

Reaksi PCR dilakukan menggunakan $25 \mu \mathrm{l}$ campuran reaktan yang masing-masing mengandung $1 \mu \mathrm{l}$ primer forward dan reverse (200nM), $12,5 \mu \mathrm{l} \mathrm{Go}$ Taq Green Master Mix yang terdiri dari Go Taq DNA polymerase, bufer PCR, 3mM MgCl2, dan dNTP, DNA/ RNA free water, dan cetakan DNA genom. Protokol $\mathrm{PCR}$ yang digunakan adalah pre-denaturasi $\left(94^{\circ} \mathrm{C}, 5\right.$ menit), denaturasi ( $94^{\circ} \mathrm{C}, 1$ menit), penempelan primer (55 ${ }^{\circ} \mathrm{C}, 1$ menit), ekstensi $\left(72{ }^{\circ} \mathrm{C}, 1\right.$ menit) dan final extention $\left(72^{\circ} \mathrm{C}, 7\right.$ menit) dengan siklus sebanyak 35 kali. Sebanyak 6-7 $\mu$ l hasil PCR dielektroforesis pada gel agarosa $2 \%(w / v)$, dengan menggunakan bufer TBE1X pada $100 \mathrm{~V}$ selama 45 menit. Identifikasi menggunakan kontrol positif yaitu $V$. parahaemolyticus ATCC43996 untuk gen tdh dan V. parahaemolyticus AQ4037 untuk gen trh.

\section{HASIL DAN BAHASAN}

Prevalensi V. parahaemolyticus dari total 64 sampel udang yang berasal dari tambak tradisional dan intensif berturut-turut diketahui sebanyak 16/32 (50\%) dan 6/32 (18,75\%). Hasil ini menunjukkan bahwa prevalensi $V$. parahaemolyticus pada udang tambak tradisional lebih tinggi dibandingkan tambak intensif. $V$. parahaemolyticus merupakan bakteri yang secara alami terdapat di perairan laut, pantai, muara sungai maupun budidaya tambak. Keberadaan $V$. parahaemolyticus pada lingkungan perairan laut yang umumnya diisolasi dari air laut, sedimen, maupun berbagai jenis produk perikanan, telah banyak ditemukan seperti di Indonesia, Jepang, Korea, Thailand, India, dan negara Eropa serta Amerika. $V$. parahaemolyticus merupakan bakteri yang bersifat patogen pada udang dan manusia karena dapat menyebabkan penyakit melalui konsumsi pangan.

Penelitian yang menunjukkan besarnya prevalensi V. parahaemolyticus di produk perikanan maupun lingkungan di Indonesia telah dilakukan namun informasinya masih terbatas sekali. Marlina et al. (2007) menyebutkan bahwa 100\% sampel kerang $(n=47)$ yang diambil dari perairan dan pasar lokal di Padang-Sumatera Barat diketahui positif $V$. parahaemolyticus. Sementara itu hasil penelitian Dewanti-Hariyadi et al. (2002) menunjukkan bahwa udang yang diambil dari tambak di Jawa Barat dan Jawa Tengah mengandung $V$. parahaemolyticus sebesar 21,8 dan $3,1 \%$, sedangkan sampel udang 
beku dari pasar grosir positif $V$. parahaemolyticus sebesar $11,1 \%$, bahkan pada produk udang beku selama proses pembekuan sebesar $70 \%$.

Zulkifli et al. (2009) melaporkan persentase $V$. parahaemolyticus pada sampel kerang yang berasal dari perairan di Padang-Sumatera Barat sebesar 50\% $(n=50)$. Hal ini kemungkinan karena iklim tropis dengan kisaran suhu $25-35^{\circ} \mathrm{C}$ merupakan suhu yang mendukung pertumbuhan $V$. parahaemolyticus. Sebagian besar wilayah dengan iklim tropis khususnya Asia Tenggara diketahui berpotensi terhadap keberadaan $V$. parahaemolyticus dengan persentase sekitar 20-70\% (Wong et al., 1999; Ronald \& Santos, 2001). Saat pengambilan sampel udang baik di tambak tradisional maupun intensif, suhu air tambak terukur pada kisaran $30-31^{\circ} \mathrm{C}$. Suhu perairan ini diduga menjadi faktor yang dapat membantu pertumbuhan $V$. parahaemolyticus karena merupakan suhu optimum pertumbuhan bakteri tersebut.

Penelitian keberadaan V. parahaemolyticus pada produk perikanan juga telah banyak dilakukan oleh negara-negara di luar Indonesia. Wong et al. (1999) menyebutkan bahwa ditemukan $45,9 \%(n=686) \mathrm{V}$. parahaemolyticus pada produk perikanan (kepiting, lobster, udang, siput, dan ikan) yang diimpor dari Vietnam, Hong Kong, Thailand, dan Indonesia, di mana sebesar $75,8 \%$ ( $n=62)$ dan 29,3\% ( $n=92)$ pada sampel udang dan ikan yang berasal dari Indonesia positif $V$. parahaemolyticus. Sementara itu, udang yang berasal dari budidaya tambak di Malaysia menunjukkan 81,7\% $(n=60)$ mengandung $V$. parahaemolyticus (Chilek, 2006). Sebanyak $43,6 \%(n=39)$ dari sampel seafood mentah (cumi-cumi, udang, ikan, dan kekerangan), dan $6,3 \%(n=16)$ sampel produk olahan (bakso udang) di Thailand juga diketahui positif $V$. parahaemolyticus (Chitov et al., 2009). Sampel udang, kepiting, moluska, dan ikan yang diambil dari tempat pendaratan ikan, pasar, dan estuari di India diketahui mengandung $V$. parahaemolyticus sebesar $61,6 \%$ $(n=86)$, selain itu sampel udang yang berasal dari tambak di India baik dari wilayah barat maupun timur diketahui positif $V$. parahaemolyticus berturut-turut 12,2 dan 2,8\% ( $n=30)$ (Dileep et al., 2003; Gopal et al., 2005). Tingginya peluang terjadinya $V$. parahaemolyticus pada produk perikanan menuntut perhatian khusus karena dapat berdampak terhadap kesehatan jika produk perikanan tersebut terkontaminasi V.parahaemolyticus patogenik. V. parahaemolyticus merupakan salah satu spesies Vibrio yang dapat menyebabkan penyakit pada manusia melalui konsumsi pangan terutama pangan mentah atau yang tidak dimasak secara sempurna. Namun demikian tidak semua galur $V$. parahaemolyticus bersifat patogen. Untuk itu perlu dilakukan identifikasi terhadap V. parahaemolyticus patogenik pada produk-produk perikanan.

Prevalensi $V$. parahaemolyticus patogenik dengan target gen $t d h$ yang diisolasi dari udang tambak tradisional maupun intensif berturut-turut sebesar 81,3\% (13/16) dan 50\% (3/6) seperti yang tersaji pada Gambar 1 dan 2.

Sementara itu berdasarkan target gen trh, hasil amplifikasi DNA dari isolat $V$. parahaemolyticus pada sampel udang di tambak tradisional maupun intensif berturut-turut sebesar $15 / 16$ isolat $(93,8 \%)$ dan $4 / 6$ isolat $(66,7 \%)$ positif gen trh (Gambar 3 dan 4 ).

Berdasarkan pengelompokan gen $t d h$ dan trh isolat V. parahaemolyticus dari sampel udang yang berasal dari tambak tradisional dan intensif, beberapa isolat diketahui memiliki kedua gen patogen ( $t d h$ dan $t r h$ ) yaitu sebesar $63,6 \%(14 / 22)$ isolat. Sedangkan beberapa isolat $V$. parahaemolyticus dari sampel

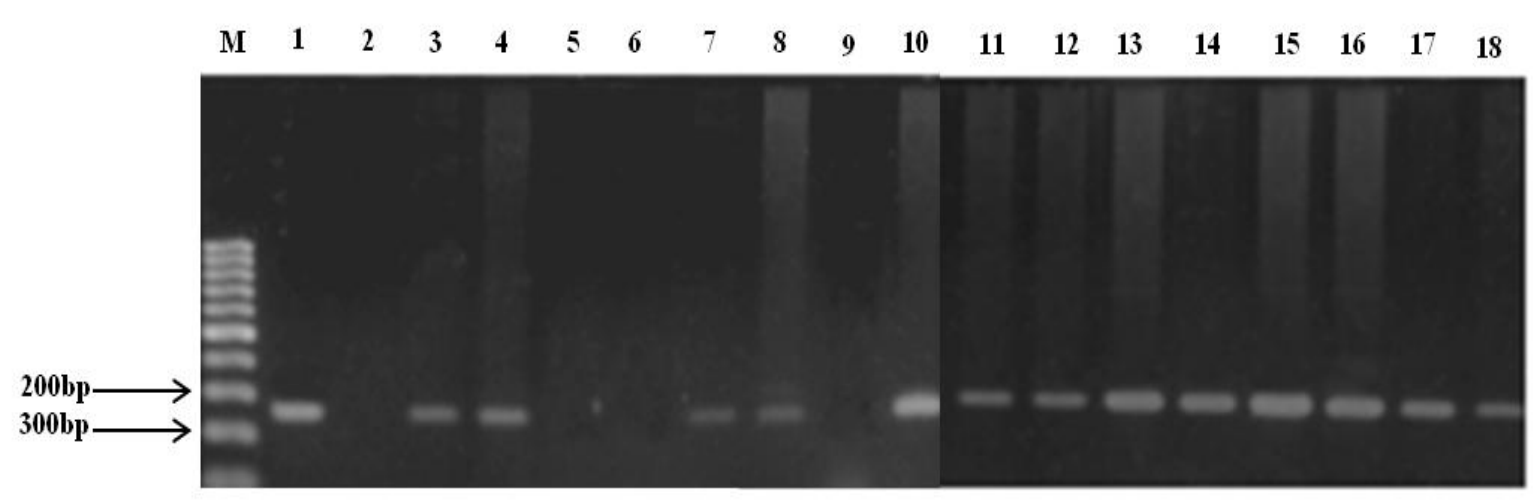

Gambar 1. Visualisasi gen tdh V. parahaemolyticus dari sampel udang tambak tradisional. M : marker DNA $100 \mathrm{bp}, 1$ : kontrol positif (ATCC43996), 2 : kontrol negatif, 3-18: sampel udang dari tambak tradisional.

Figure 1. Visualization of tdh gene of $\mathrm{V}$. parahaemolyticus from traditional shrimp culture. $M$ : DNA marker 100 bp, 1 : positive control (ATCC43996), 2 : negative control, 3-18: samples. 


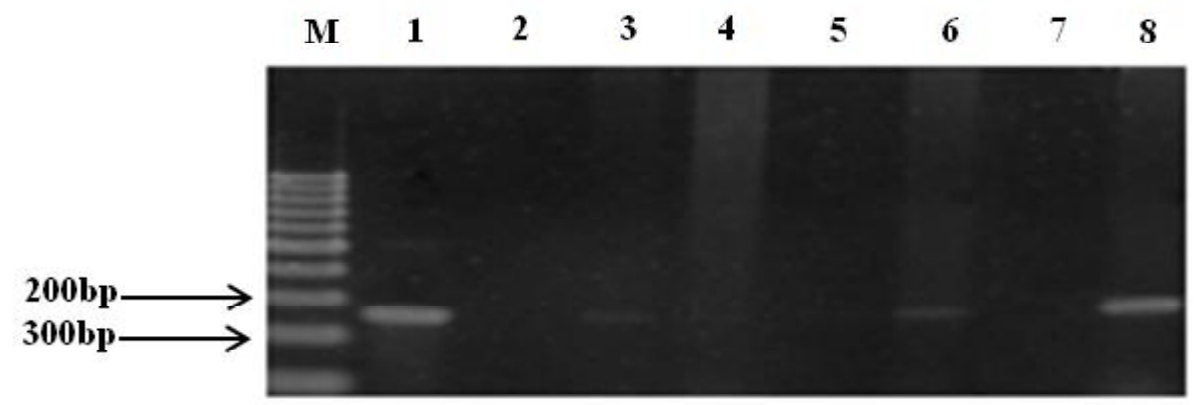

Gambar 2. Visualisasi gen tdh $V$. parahaemolyticus dari sampel udang tambak intensif. M : marker DNA 100bp, 1 : kontrol positif (ATCC43996), 2 : kontrol negatif, 3-8 : sampel udang dari tambak intensif.

Figure 2. Visualization of tdh gene of $\mathrm{V}$. parahaemolyticus from intensive shrimp culture. $M$ : DNA marker 100bp, 1 : positive control (ATCC43996), 2 : negative control, 3-8 : samples.

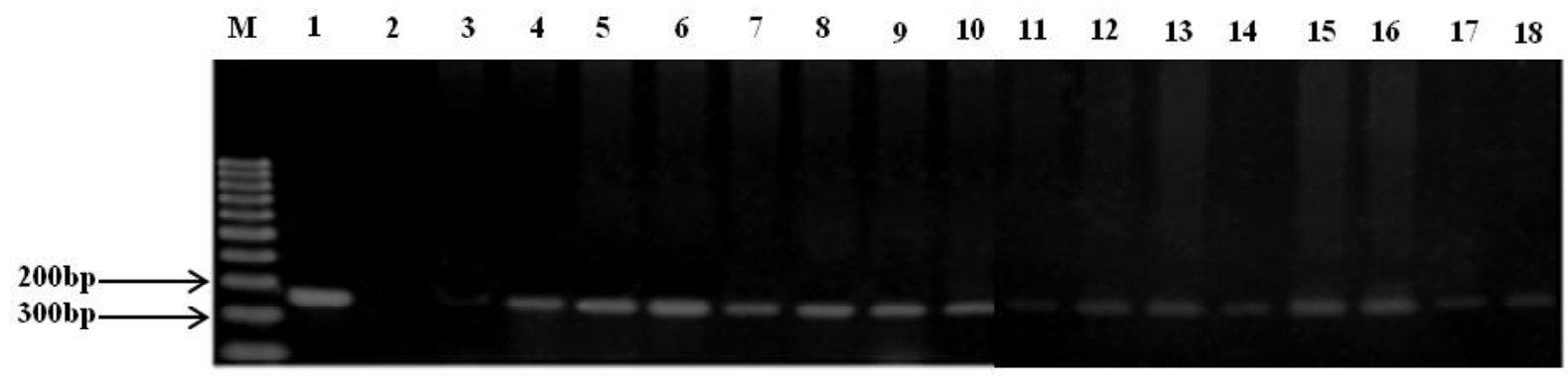

Gambar 3. Visualisasi gen trh V. parahaemolyticus dari sampel udang tambak tradisional. M : marker DNA $100 \mathrm{bp}, 1$ : kontrol positif (AQ4037), 2: kontrol negatif, 3-18:sampel udang dari tambak tradisional.

Figure 3. Visualization of trh gene of $\underline{V}$. parahaemolyticus from traditional shrimp culture. $M$ : DNA marker 100 bp, 1 : positive control (AQ4037), 2 : negative control, 3-18: samples.

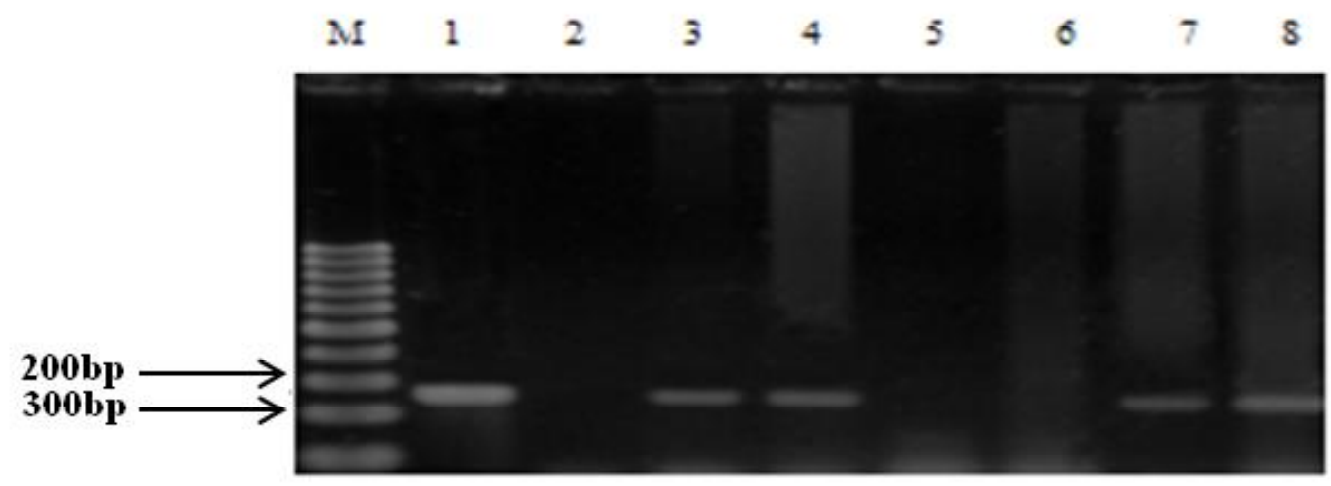

Gambar 4. Visualisasi gen trh V. parahaemolyticus dari sampel udang tambak intensif. M : marker DNA 100 bp, 1 : kontrol positif (AQ4037), 2 : kontrol negatif, 3-8 : sampel udang dari tambak intensif.

Figure 4. Visualization of trh gene of $\underline{V}$. parahaemolyticus from intensive shrimp culture. $M$ : DNA marker 100 bp, 1 : positive control (AQ4037), 2 : negative control, 3-8 : samples. 
udang yang berasal dari tambak tradisonal maupun intensif hanya memiliki salah satu gen saja (gen $t d h$ ) atau (gen trh) berturut-turut adalah sebesar 2/22 isolat $(9,1 \%)$ dan $5 / 22$ isolat $(22,7 \%)$ (Tabel 1$)$.

Berdasarkan data prevalensi yang telah dihasilkan, diketahui bahwa $V$. parahaemolyticus patogenik berpotensi terdapat pada udang tambak yang berasal dari tradisional maupun intensif. Tingginya persentase keberadaan bakteri patogen pada udang tambak yang berasal dari tambak tradisional maupun intensif merupakan cerminan masih rendahnya kesadaran petambak udang dalam menerapkan praktek berbudidaya yang baik (Good Aquaculture Practices/ GAP) terutama pada tambak tradisional. $V$. parahaemolyticus merupakan bakteri alami yang hidup di air payau, sehingga kemungkinan keberadaannya pada tambak udang cukup tinggi karena penggunaan air payau selama pemeliharaan udang.

Berdasarkan pengamatan di lapangan tambak udang tradisional yang dijadikan sebagai tempat pengambilan sampel, jauh dari praktek penerapan GAP. Hal ini dapat dilihat dari tidak tersedianya tempat penampungan air sementara sebelum dialirkan ke areal tambak sehingga air langsung masuk ke tambak tanpa ada perlakuan untuk memenuhi persyaratan kualitas air. Hal ini menyebabkan potensi keberadaan bakteri cukup besar termasuk V. parahaemolyticus. Selain itu petambak juga jarang memperhatikan pengelolaan

Tabel 1. Distribusi gen tdh dan trh pada isolat $V$. parahaemolyticus dari sampel udang di tambak tradisional dan intensif.

Table 1. Distribution of $t d h$ and trh genes of $\underline{V}$. parahaemolyticus isolates from traditional and intensive shrimp cultures

\begin{tabular}{|c|c|c|}
\hline Isolat/Isolates & $\begin{array}{c}\text { gen } \\
\text { tdh/tdh } \\
\text { gene }\end{array}$ & $\begin{array}{c}\text { gen } \\
\text { trh/trh } \\
\text { gene }\end{array}$ \\
\hline \multicolumn{3}{|l|}{ Tambak tradisional/ Traditional pond: } \\
\hline TrA1 & + & - \\
\hline TrB2 & + & + \\
\hline TrC2 & - & + \\
\hline TrF2 & - & + \\
\hline TrG1 & + & + \\
\hline Trl1 & + & + \\
\hline TrJ1 & - & + \\
\hline TrK1 & + & + \\
\hline TrK2 & + & + \\
\hline TrL1 & + & + \\
\hline TrM1 & + & + \\
\hline TrN2 & + & + \\
\hline TrO1 & + & + \\
\hline TrO2 & + & + \\
\hline TrP1 & + & + \\
\hline TrP2 & + & + \\
\hline Gen tdh dan trh positif/tdh and trh genes positive & \multicolumn{2}{|c|}{$12 / 16(75 \%)$} \\
\hline Gen $t d h$ positif/tdh gene positive & \multicolumn{2}{|c|}{$1 / 16(6,25 \%)$} \\
\hline Gen trh positif/trh gene positive & \multicolumn{2}{|c|}{$3 / 16(18,75 \%)$} \\
\hline \multicolumn{3}{|l|}{ Tambak intensif/ Intensive pond: } \\
\hline IntB1 & + & + \\
\hline IntB2 & - & + \\
\hline IntC1 & - & - \\
\hline IntC2 & + & - \\
\hline IntG2 & - & + \\
\hline IntO1 & + & + \\
\hline Gen tdh dan trh positif/tdh and trh genes positive & \multicolumn{2}{|c|}{$2 / 6(33,3 \%)$} \\
\hline Gen $t d h$ positif/tdh gene positive & \multicolumn{2}{|c|}{$1 / 6(16,7 \%)$} \\
\hline Gen trh positif/trh gene positive & \multicolumn{2}{|c|}{$2 / 6(33,3 \%)$} \\
\hline
\end{tabular}

Keterangan/Note: $(+)$ : hasil uji positif/postive result

$(-)$ : hasil uji negatif/negative result 
kualitas air. Beberapa parameter penting seperti salinitas, $\mathrm{pH}$, oksigen terlarut, dan kekeruhan tidak selalu terukur secara periodik sehingga berdampak terhadap kualitas dan kuantitas udang yang dihasilkan.

Penerapan sistim aerasi pada lahan tambak merupakan hal penting. Pada umumnya luas areal tambak tradisional berkisar 5.000-10.000 $\mathrm{m}^{2}$ dan idealnya pada tambak tersebut ditempatkan aerator sekitar empat unit. Tambak tradisional memiliki sistim yang statis di mana tidak ada penggantian air tambak sampai waktu panen. Pemberian pakan alami selama periode pemeliharaan udang memberikan peluang kontaminasi bakteri yang cukup besar. Hasil pengamatan dan wawancara dengan petambak tradisional menginformasikan bahwa para petambak membuat sendiri pakan udang dengan cara menghaluskan campuran ikan-ikan rucah yang kemudian dijemur dan dibentuk seperti pelet. Kualitas ikan kondisi sanitasi lingkungan dan higiene personal dalam pembuatan pakan udang menjadi hal penting yang harus diperhatikan untuk menghasilkan kualitas pakan udang yang baik.

Hasil penelitian lain juga memberikan informasi tentang adanya $V$. parahaemolyticus patogenik pada produk perikanan. Bej et al. (1999) melaporkan bahwa sebesar 23,3; 46,7; dan 68,4\% V. parahaemolyticus yang diisolasi dari produk perikanan, lingkungan tambak, dan tiram merupakan $V$. parahaemolyticus yang memiliki gen $t d h$ dan trh, sedangkan sebanyak 9,3\% dari produk perikanan dan 5,2\% dari tambak tiram merupakan $V$. parahaemolyticus penghasil gen tdh.

Prevalensi V. parahaemolyticus patogenik pada awalnya dilaporkan hanya berkisar $1-5 \%$ pada sampel-sampel lingkungan dan produk perikanan (Sakazaki et al., 1968; Miyamoto et al., 1969; Kelly \& Stroh, 1988; Kiiyukia et al., 1989; Ogawa et al., 1989; Nishibuchi \& Kaper, 1995; Cook et al., 2002; Hervio-Heath et al., 2002; Robert-Pillot et al., 2004). Hal ini diduga karena keberadaan galur $V$. parahaemolyticus patogenik lebih rendah dibandingkan galur yang non patogenik atau galur patogenik lebih sensitif pada kondisi lingkungan yang ekstrim sehingga cepat sekali berubah ke dalam bentuk viable but nonculturable (VNC) dan menjadi sulit untuk diisolasi (Jannasch, 1967; Roszak \& Colwell,1987; Hackney \& Dicharry, 1988; Pace \& Chai,1989).

Berdasarkan hasil penelitian ini diketahui bahwa V. parahaemolyticus patogenik pada sampel udang tambak memiliki persentase yang cukup tinggi. Hasil ini cukup kontras dengan hasil penelitian yang telah dilaporkan sebelumnya. Namun demikian beberapa hasil penelitian lain juga melaporkan bahwa keberadaan $V$. parahaemolyticus patogenik memiliki peresentase cukup tinggi. Marlina et al. (2007) melaporkan bahwa sebesar $36 \%$ dari 47 isolat $V p$ pada sampel kerang yang berasal dari perairan dan pasar lokal di Padang-Sumatera Barat teridentifikasi gen tdh. Penelitian Sujeewa et al. (2009) melaporkan bahwa 15 dan $7 \%$ isolat yang berasal dari sampel lingkungan tambak (sedimen dan air) dan udang beku di Malaysia berturut-turut positif gen $t d h$ dan trh. Sementara itu Mohammad et al. (2005) menyatakan bahwa sebesar 8 dan 11\% sampel udang beku dan udang segar teridentifikasi $V$. parahaemolyticus patogenik. Yingkajorn et al. (2014) menyebutkan bahwa prevalensi $V$. parahaemolyticus patogenik pada udang vaname yang siap panen di Thailand sebesar 14/88 $(15,9 \%)$ untuk gen tdh dan 4/88 (4,6\%) untuk gen trh. Peningkatan sampel produk perikanan yang mengandung $V$. parahaemolyticus patogenik (gen tdh) juga dilaporkan oleh DePaola et al. (2003a) yaitu sebesar $12,8 \%$ pada sampel tiram. Selanjutnya HaraKudo et al. (2003) melaporkan bahwa sekitar 10\% $(n=329)$ isolat dari sampel produk perikanan perairan dan pasar di Jepang mengandung gen $t d h$. Pinto et al. (2008) menyatakan sebesar 33\% sampel kekerangan yang berasal dari perairan pantai Italia dideteksi positif gen $t d h$, bahkan hasil penelitian DePaola et al. (2003b) pada sampel makanan dan lingkungan selama kurun waktu 1977-2001 menunjukkan lebih dari $90 \%$ isolat positif gen $t d h$ dan trh.

Identifikasi keberadaan bakteri V. parahaemolyticus pada sampel lingkungan dan produk perikanan dipengaruhi oleh beberapa faktor, salah satunya adalah pemilihan metode analisis yang digunakan (Parveen et al., 2008). Selain itu tahap isolasi bakteri yang merupakan tahap awal identifikasi bakteri diduga memberikan persentase yang lebih tinggi terutama yang berasal dari sampel lingkungan dan produk perikanan.

Pada penelitian ini, identifikasi V. parahaemolyticus diawali dengan tahap isolasi di mana sampel udang tambak diinkubasi pada media ASPW yang merupakan media pengayaan. Teknik ini merupakan salah satu teknik yang dapat memberikan persentasi V. parahaemolyticus lebih tinggi karena diduga tahap pengayaan merupakan tahap pemulihan (recovery) terutama bakteri-bakteri dalam kondisi sakit.

Raghunath et al. (2009) melaporkan bahwa pada umumnya galur $V$. parahaemolyticus patogenik jarang ditemukan pada sampel lingkungan dan produk perikanan, hal ini disebabkan galur patogen lebih sensitif pada lingkungan perairan yang tidak kondusif sehingga galur ini dapat berubah menjadi viable but nonculturable (VNC). Fase ini merupakan fase dorman bakteri di mana pada fase ini bakteri tidak dapat 
bermultiplikasi tetapi masih dapat melakukan aktivitas metabolisme. Penyebab terjadinya fase ini umumnya disebabkan karena kondisi lingkungan perairan yang tidak kondusif seperti fluktuasi suhu, salinitas, pH yang cukup tinggi, kandungan nutrien perairan yang tidak mendukung sehingga memberikan pengaruh terhadap populasi mikroorganisme di perairan tersebut termasuk V. parahaemolyticus. Kondisi ini dapat menyebabkan sulitnya mengisolasi $V$. parahaemolyticus patogenik dari lingkungan dan produk perikanan. Untuk mengatasi hal tersebut, tahap pengayaan merupakan salah satu altenatif pengembangan metode analisis yang dapat dilakukan sehingga persentase frekuensi isolasi $V$. parahaemolyticus patogenik dapat meningkat.

Hasil penelitian Raghunath et al. (2009) melaporkan bahwa identifikasi $V$. parahaemolyticus patogenik yang dikayakan terlebih dahulu dengan media cair APW (alkaline peptone water) dan ST (sodium taurocholate) memberikan frekuensi isolasi yang lebih tinggi. Identifikasi $V$. parahaemolyticus patogenik berdasarkan gen penyandi tdh dan trh pada sampel kekerangan, ikan, udang di perairan pantai dan tambak udang di India memberikan hasil berturutturut sebesar 32,8 dan 41,4\% untuk gen trh dan 13,8 dan 20,7\% untuk gen tdh. Pada awalnya identifikasi V. parahaemolyticus patogenik dilakukan berdasarkan reaksi biokimiawi yang dikenal dengan Fenomena Kanagawa $(\mathrm{KP}+)$. Metode ini terutama dapat mengidentifikasi faktor virulen TDH yang ditandai dengan $\mathrm{KP}+$, akan tetapi faktor virulen $\mathrm{TRH}$ tidak dapat diidentifikasi dengan metode analisis ini, di mana diketahui hasil KP- ternyata memberikan hasil yang dapat menyebabkan penyakit pada manusia. Selain itu beberapa kendala yang dialami teknik konvensional adalah waktu analisis yang panjang, interpretasi hasil yang tidak cukup akurat dan sensitifitas teknik analisis yang masih cukup rendah, terutama pada isolat bakteri yang berada pada fase VNC (viable but non culturable). Teknik identifikasi $V$. parahaemolyticus patogenik kemudian berkembang karena masih terbatasnya hasil analisis yang berdasarkan metode biokimiawi. Salah satu pengembangan teknik identifikasi adalah metode PCR. Beberapa hasil penelitian dengan teknik PCR menunjukkan hasil yang cukup signifikan dalam hal identifikasi V. parahaemolyticus patogenik. Zimmermann et al. (2007) melaporkan hasil deteksi gen tdh dan/atau trh) dengan real time PCR pada sampel tiram di perairan Mississippi dan Alabama berturut-turut sebesar 56\% dan 44\%. Sementara itu Parveen et al. (2008) menyatakan bahwa $20 \%$ dan $40 \%$ isolat dari sampel tiram yang diambil perairan di Amerika Serikat teridentifikasi positif gen tdh dan trh.

\section{KESIMPULAN}

Prevalensi V. parahaemolyticus pada udang tambak tradisional dan intensif berturut-turut adalah 50\% (16/32) dan 18,8\% (6/32). Hasil penelitian ini menunjukkan bahwa prevalensi $V$. parahaemolyticus pada udang di tambak tradisional lebih tinggi dibandingkan tambak intensif. Hasil konfirmasi secara genetika $V$. parahaemolyticus patogenik pada udang di tambak tradisional dan intensif berdasarkan gen td $h$ berturut-turut adalah $13 / 16(81,3 \%)$ isolat dan $3 / 6$ $(50 \%)$ isolat sedangkan trh $15 / 16(93,8 \%)$ isolat dan $4 / 6(66,7 \%)$ isolat. Sementara itu berdasarkan pengelompokan gen penyandi $t d h$ dan $t r h$, diketahui sebanyak 14/22 (63,6\%) isolat dari udang tambak tradisional maupun intensif memiliki kedua gen tersebut (tdh dan trh), sedangkan sebanyak 2/22 $(9,1 \%)$ dan $5 / 22(22,7 \%)$ isolat diketahui hanya memiliki gen $t d h$ atau trh saja.

\section{DAFTAR PUSTAKA}

Ausubel, F.M., Brent, R., Kingston, R.E., Moore, D.D., Seidman, J.G., Smith, J.A., \& Struhl, K. (1987). Current Protocols in Molecular Biology. New York-Wiley.

Bej, A.K., Patterson, D.P., Brasher, C.W., Vickery, M.C., Jones, D.D., \& Kaysner, C.A. (1999). Detection of total and hemolysin-producing Vibrio parahaemolyticus in shellfish using multiplex PCR amplification of $\mathrm{tl}$, tdh, and trh. Journal of Microbiology Methods, 36, 215-225.

Bhunia, A.K. (2008). Foodborne Microbial pathogens: Mechanism and pathogenesis. Food Science Text Series. Springer.

Broberg,C.A., Calder, T.J., \& Orth, K. (2011). Vibrio parahaemolyticus cell biology and pathogenicity determinants. Microbes Infect., 13, 992-1001. doi: 10.1016/j.micinf.2011.06.013.

Brown T.A. 1992. Genetics: Molecular Approach, Second Edition. Chapman dan Hall, London.

Chilek,TZT. (2006). Prevalence and molecular characteristic of Vibrio parahaemolyticus isolated from cultured tiger prawns (Penaeus monodon) from Malacca. Thesis. University Putra Malaysia.

Chitov, T., Wongdao, S., Thatum, W., Puprae, T., \& Sisuwan, P. (2009). Occurrence of potentially pathogenic Vibrio species in raw, processed, and ready to eat seafood and seafood products. Maejo Int. J. Sci. Technol., 3(01): 88-98.

Cook, D.W., O'Leary, P., Hunsucker, J.C., Sloan, E.M., Bowers, J.C., Blodgett, R.J., \& DePaola, A. (2002). Vibrio vulnificus and Vibrio parahaemolyticus in U.S. retail shell oysters: a national survey June 1998 to July 1999. Journal of Food Protection, 65, 79-87.

Daniels, N. A., MacKinnon, L., \& Bishop, R. (2000). Vibrio parahaemolyticus infections in the United States, 1973-1998. Journal of Infectious Diseases, 181, 1661-1666. 
DePaola, A., Kaysner, C.A., Bowers, J.C., \& Cook, D.W. (2000). Environmental investigations of Vibrio parahaemolyticus in oysters following outbreaks 83 in Washington, Texas, and New York (1997 and 1998). Appl. Environ. Microbiol., 66, 4649-4654.

DePaola, A., Nordstrom, J.L., Bowers, J.C., Wells, J.G., \& Cook, D.W. (2003a). Seasonal Abundance of Total and Pathogenic Vibrio parahaemolyticus in Alabama Oysters. Appl. Environ. Microbiol., 69(3), 1521-1526.

DePaola, A., Ulaszek, J., Kaysner, C.A., Tenge, B.J., Nordstrom, J.L., Wells, J., Puhr, N., \& Gendel, S.M. (2003b). Molecular, Serological, and Virulence Characteristics of Vibrio parahaemolyticus isolated from environmental, food, and clinical sources in North America and Asia. Appl. Environ. Microbiol., 69, 3999-4005.

Dewanti-Hariyadi, R., Suliantari, Nuraida, L., \& Fardiaz, S. (2002). Determination of contamination profiles of human bacterial pathogens in shrimp obtained from Java, Indonesia. Proceedings of a Final Research Coordination Meeting held in Mexico City, Mexico, 2226 July 2002. Mexico: IAEA-Tecdoc-1431.

Dileep, V., Kumar, HS., Kumar, Y., Nishibuchi, M., Karunasagar, I., \& Karunasagar, I. (2003). Application of polymerase chain reaction for detection of Vibrio parahaemolyticus associated with tropical seafoods and coastal environment. Letters in Applied Microbiology, 36, 423-427.

Eja, M., Abriba, C., Etok, C., Ikpeme, E., Arikpo, G., EnyiIdoh, K., \& Ofor, U. (2008). Seasonal occurrence of Vibrios in water and shellfish obtained from the Great Kwa River Estuary, Calabar, Nigeria. Bulletin of Environmental Contamination and Toxicology, 81, 245-248.

Farmer, III.JJ., Janda, J M., dan Birkhead, K. 2003. Vibrio. In Murray, PR., Baron, EJ., Jorgensen, JA., Pfaller, MA., and Yolken, RH. (eds.). Manual of Clinical Microbiology (8th ed., Vol. 1, pp. 706-719). Washington, DC: ASM Press.

Gopal, S., Ottaa, S.K., Kumar, S., Karunasagar, I., Nishibuchi, M., \& Karunasagar, I. (2005). The occurrence of Vibrio species in tropical shrimp culture environments; implications for food safety. Int. J. Food Microbiol, 102, 151-159.

Hackney, C.R. \& Dicharry, A. (1988). Seafood-borne bacterial pathogens of marine origin. Food Technology, 42, 104-109.

Hara-Kudo, Y., Sugiyama, K., Nishibuchi, M., Chowdhury, A., Yatsuyanagi, J., Ohtomo, Y., Saito, A., Nagano, H., Nishina, T., Nakagawa, H., Konuma, H., Miyahara, M., \& Kumagai, S. (2003). Prevalence of pandemic thermostable direct hemolysin-producing Vibrio parahaemolyticus O3:K6 in seafood and the coastal environment in Japan. Appl. Environ. Microbiol., 69 (7), 3883-3891.

Hervio-Heath, D., Colwell, R. R., Derrien, A., Robert-Pillot, A., Fournier, J.M., \& Pommepuy, M. (2002). Occurrence of pathogenic Vibrios in coastal areas of France. Journal of Applied Microbiology, 92, 1123-1135.

Honda, T. \& lida, T. (1993). The pathogenicity of Vibrio parahaemolyticus and the role of thermostable direct haemolysin and related haemolysins. Reviews in Medical Microbiology, 4, 106-113.

Jannasch, H.W. (1967). Growth of marine bacteria at limiting concentrations of organic carbon in seawater. Limnology and Oceanography, 12, 264-271.

Kaufman, G.E., Myers, M.L., Pass, C.L., Bej, A.K., \& Kaysner, C.A. (2002). Molecular analysis of Vibrio parahaemolyticus isolated from human patients and shellfish during US Pacific north-west outbreaks. Letters in Applied Microbiology, 34, 155-161.

Kelly, M.T. \& Stroh, E.M.D. (1989). Urease-positive, Kanagawa-negative Vibrio parahaemolyticus from patients and the environment in the Pacific Northwest. J. Clin. Microbiol, 27, 2820-2822.

Kaysner, CA. \& DePaola, A. (2001). Vibrio. In Downes, F.P. and Ito, K. (ed.). Microbiological Examination of Foods (pp. 405-428). American Public Health Association, Washington, D.C.

Kaysner, C.A. \& DePaola, A. (2004). Bacteriological Analytical Manual Chapter 9. Vibrio. Bacteriological Analytical Manual, 8 thed. 2001. U.S. Food and Drug Administration. Arlington, VA: Association of Official Analytical Chemists.

Kiiyukia, C., Venkateswaran, K., Navarro, I. M., Nakano, H., Kawakami, H. \& Hashimoto, H. (1989). Seasonal distribution of Vibrio parahaemolyticus serotypesalong the oyster beds in Hiroshima coast. Journal of Applied and Biology Science, 28, 49-61.

Lutz, C., Erken, M., Noorian, P., Sun, S., \& McDougald, D. (2013). Environmental reservoirs and mechanisms of persistence of Vibrio cholerae. Frontiers in Microbiology, 4, 375-380.

Makino, K., Oshima, K., Kurokawa, K., Yokoyama, K., Uda, T., \& Tagomori, K. (2003). Genome sequence of Vibrio parahaemolyticus: a pathogenic mechanism distinct from that of Vibrio cholerae. Lancet, 361, 743-749. doi:10.1016/S0140-6736(03)12659-1.

Marlina, Radu, S., Kqueen, C.Y., Napis, S., Zakaria, Z., Mutalib, S.A., \& Nishibushi, M. (2007). Detection of $t d h$ and trh genes in Vibrio parahaemolyticus isolated from Corbicula moltkiana prime in West Sumatera, Indonesia. Southeast Asian Journal of Tropical Medicine and Public Health, 38(2), 349-355.

Miyamoto, Y., Kato, T., Obara, Y., Akiyama, S., Takizawa, K., \& Yama, S. (1969). In vitro hemolytic characteristic of Vibrio parahaemolyticus: Its close correlation with human pathogenicity. J. Bacteriol., 100, 1147-1149.

Mohammad, A.R., Hashim, J.K., Gunasalam, J., \& Radu, S. (2005). Microbiological risk assessment: Risk Assessment of Vibrio parahaemolyticus in black tiger prawn (Penaeus monodon). Technical report, Ministry of Health Malaysia.

Newton, A., Kendall, M., Vugia, D.J., Henao, O.L., and Mahon, B.E. (2012). Increasing rates of vibriosis in the United States,1996-2010: review of surveillance data from 2 systems. Clin. Infect.Dis., 54, S391S395. doi:10.1093/cid/cis243.

Nishibuchi, M. \& Kaper, J.B. (1995). Thermostable direct haemolysin gene of Vibrio parahaemolyticus: A virulence gene acquired by a marine bacterium. Infection and Immunity, 63, 2093-2099. 
Ogawa, H., Tokunou, H., Kishimoto, T., Fukuda, S., Umemura, K. \& Takata, M. (1989). Ecology of Vibrio parahaemolyticus in Hiroshima Bay. Hiroshima Journal of Veterinary Medicine, 4, 47-57.

Pace, J. and Chai, T. 1989. Comparison of Vibrio parahaemolyticus grown in estuarine water and rich medium. Appl. Environ. Microbiol., 55, 1877-1887.

Parveen, S., Hettiarachchi, K.A., Bowers, J.C., Jones, J.L., Tamplin, M.L., McKay, R. et al. (2008). Seasonal distribution of total and pathogenic Vibrio parahaemolyticus in Chesapeake Bay oysters and waters. Int. J. Food Microbiol, 128, 354-361.

Pinto, AD., Ciccarese, G., Corato, RD., Novello, L., \& Terio, V. (2008). Detection of pathogenic Vibrio parahaemolyticus in southern Italian shellfish. Food Control, 19, 1037-1041.

Potasman, I., Paz, A., \& Odeh, M. (2002). Infectious outbreaks associated with bivalve shellfish consumption: a worldwide perspective. Clin Infect Dis., 35(8), 921-928.

Raghunath, P., Karunasagar, I., \& Karunasagar, I. 2009. Improved isolation and detection of pathogenic Vibrio parahaemolyticus from seafood using a new enrichment broth: Short Communication. Int. J. Food Microbiol., 129, 200-203.

Robert-Pillot, A., Guenole, A., Lesne, J., Delesmont, R., Fournier, J.M., \& Quilici, M.L. (2004). Occurrence of the tdh and trh in Vibrio parahaemolyticus isolates from waters and raw shellfish collected in two French coastal areas and from seafood imported into France. Int. J. Food Microbiol., 91, 319-325.

Ronald, G.L. \& Santos, G. (2001). Guide to foodborne pathogens. New York: John Wiley and Sons, Inc.

Roszak, D.B. \& Colwell, R.R. (1987). Survival strategies in the natural environment. Microbiology and Molecular Biology Reviews, 51, 365-379.

Sakazaki, R., Tamura, K., Kato, T., Obara, Y., Yamai, S. \& Hobo, K. (1968). Studies on the enteropathogenic, facultatively halophilic bacteria, Vibrio parahaemolyticus. III. Enteropathogenicity, Japan. J. Med Sci Biol., 21, 325-331.

Shirai, H., Ito, H., Hirayama, T., Nakamoto, Y., Nakabayashi, N., Kumagai, K., Takeda, Y., \& Nishibuchi, M. (1990). Molecular epidemiologic evidence for association of thermostable direct hemolysin (TDH) and TDH-related hemolysin of Vibrio parahaemolyticus with gastroenteritis. Infect. Immun., 58, 3568-3573.
Sujeewa, A.K.W., Norrakiah, A.S., \& Laina, M. (2009). Prevalence of toxic genes of Vibrio parahaemolyticus in shrimps (Penaeus monodon) and culture environment. Int. Food Research Journal, 16, 8995.

Suthienkul, O., Ishibashi, M., lida, T., Nettip, N., Supavej, S., Eampokalam, B., Makino, M., \& Honda, T. (1995). Urease production correlates with possession of the trh gene in Vibrio parahaemolyticus strains isolated in Thailand. J. Infect. Dis., 172, 1405-1408.

Tada, J., Ohashi, T., Nishimura, N., Shirasaki, Y., Ozaki, H., Fukushima, S., Takano, J., Nishibuchi, M., \& Takeda, Y. (1992). Detection of the thermostable direct hemolysin gene (tdh) and the thermostable direct hemolysin-related hemolysin gene (trh) of Vibrio parahaemolyticus by polymerase chain reaction. Mol. Cell. Probes., 6, 477-487.

Venkitanaranan, K.S. \& Doyle, M.P. (2001). Food-borne infections and infestations. In Berdanier, C.D (eds.). Handbook of Nutrition and Food (pp. 1135-1161). CRC Press, New York.

Wong, H.C, Chen, MC., Liu, SH., \& Liu, DP. (1999). Incidence of highly genetically diversified Vibrio parahaemolyticus in seafood imported from Asian countries. Int. J. Food Microbiol., 52, 181-188.

Mingkwan, Y., Mitraparp-arthorn, P., Nuanualsuwan, S., Poomwised, R., Kongchuay, N., Khamhaeng, N. \& Vuddhakul, V. (2014). Prevalence and quantification of pathogenic Vibrio parahaemolyticus during shrimp culture in Thailand. Dis Aquat Org., 112, 103-111. doi: $10.3354 /$ dao02800.

Zarei, M., Borujeni, MP., Jamnejad, A., \& Khezrzadeh, M. (2012). Seasonal prevalence of Vibrio species in retail shrimps with an emphasis on Vibrio parahaemolyticus. Food Control, 25, 107-109. doi:10.1016/j.foodcont.2011.10.024.

Zimmerman, A.M., DePaola, A., Bowers, J.C., Krantz, J.A., Nordstrom, J.L., Johnson, C.N., \& Grimes, D.J. 2007. Variability of total and pathogenic Vibrio parahaemolyticus densities in northern Gulf of Mexico water and oysters. Appl. Environ. Microbiol., 73, 7589-7596.

Zulkifli, Y., Alitheen, N.B., Radu, S., Yeap, S.K., Lesley, M.B., \& Raha, A.R. (2009). Identification of Vibrio parahaemolyticus isolates by PCR targeted to the ToxR gene and detection of virulence genes. International Food Research Journal, 16, 289-296. 